\title{
Effect of Biofertilization in Increasing the Efficiency of Two Peanut Varieties in Utilizing of Phosphorus Fertilization: 2- Effect on Yield
}

\author{
Abdel-Haliem, S. Manal"; G. M. Yakout ; H. M. Abdel-Motaleb ${ }^{*}$; A. M. Abdel-Wahab" and A. A. Nasef ${ }^{* *}$ \\ *Agronomy Department, Faculty of Agriculture, Suez Canal University \\ ${ }^{* *}$ Oil Crop Section, Agricultural Research Center, Ismailia, Egypt
}

Received: $24 / 10 / 2015$

\begin{abstract}
Two field experiments were conducted during 2012 and 2013 seasons in the Experimental Farm of Agriculture Research Station, Agric. Res. Center at Ismailia, Egypt to study the effect of four levels of phosphatic fertilizer i.e., 15.5, 23.25 and $31.0 \mathrm{~kg} \mathrm{P}_{2} \mathrm{O}_{5} / \mathrm{fad}$ (faddan= $4200 \mathrm{~m} 2$ ) with and without the bio fertilizers phosphorine or microbein on yield, yield components and yield quality of two peanut varieties, Giza 6 as erect cv and Gereogry as spread cv. The spread variety Gereogry surpassed significantly the erect variety Giza 6 in yield (pods, seeds and biological yield/fad), yield components (plant height, number and dry weight of pods/plant, dry weight of seeds /plant, 100 - seed weight and shelling percentage) and yield quality (seed oil content $\%$ and oil and protein yield/fad. While, the two studied varieties did not differ significantly from each other in dry weight of straw/plant, fodder yield/fad and seed protein content \%). Increasing phosphorus levels from 0 to $31 \mathrm{~kg} \mathrm{P}_{2} \mathrm{O}_{5} /$ fad increased significantly the forementioned yield, yield components and yield quality; expect the non significant effect of $\mathrm{P}$ levels on seed protein content \%. It is worthy to note that bio fertilizers phosphorine or microbein increased the efficiency of peanut plants in utilizing phosphours fertilizer, which in turn had favourable effect on peanut productivity. The increment of yield, yield component and yield quality of peanutcvs was more pronounced and its values were higher when peanut plants fertilized with phosphorus fertilizer combined with phosphorine or microbein than fertilized with $\mathrm{P}$ only and the two biofertilizers did not differ significantly in this respect. P levels up to the highest level $\left(31 \mathrm{~kg} \mathrm{P}_{2} \mathrm{O}_{5}\right)$ with or without biofertilizers increased significantly peanut yield, yield components and yield quality, except that there was no significant difference between to two higher levels of $\mathrm{P}\left(23.25\right.$ and $\left.31.0 \mathrm{~kg} \mathrm{P}_{2} \mathrm{O}_{5} / \mathrm{fad}\right)$ in plant height, 100-seed weight, pods yield/fad, seed oil content $\%$ and protein yield/fad.
\end{abstract}

Keywords: Biofertilization, phosphorein, microbein, yield components, peanut.

\section{INTRODUCTION}

Peanut (Arachis hypogaea L.) is one of the most important oil crops in the world and the main summer oil crop in Egypt. However, in Egypt it is not grown for oil production, but most of seed production used for industrial purposes, exporting and for fresh human consumption due to high nutritive value of seeds. In addition to green leafy hay which is used for livestock as well as it has the ability for improving the physical structure of newly reclaimed sandy soils. In 2014 season peanut average about 134146 faddan which produced about 2473652.2 ardab ( $\operatorname{ardab}=75 \mathrm{~kg}$ ) with an average 18.44 ardab per fad.

The most suitable areas for growing peanut are located in new reclaimed soils, mainly sandy soil (which represents $70 \%$ from the total peanut area), where it grows successfully in these soils. Many problems face the production of peanut in sandy soil such as low fertility of such soils, high losses of nutrients by leaching, converted nutrients such as $\mathrm{P}$ to unavailable form and the unfilled pods in the yield. So, to increase the productivity of peanut crop, intensive research work should be carried out on the crop under new reclaimed sandy soil conditions. In this respect high yielding varieties and fertilization (mineral and bio fertilization) are with great importance.

Among the major nutrients, application of phosphorus is essential for peanut growth and production. Phosphorus is one of the essential elements which play a highly recognized role in the growth and metabolism of leguminous plants (Abdel- Wahab et al., 1999 and Hafiz, 2007). Phosphorus is constituent of nucleic acids (DNA and RNA) and high energy storage compounds, stimulates cell division and metabolic processes such as photosynthesis and synthesis of protein, carbohydrates and lipids (Marschner, 1986). Also, phosphorus enhances root growth (Russel, 1973), nodulation and $\mathrm{N}$ fixation (Albert, 1978). The phosphorus content in the sandy soils is low; in addition that Egyptian soils $\mathrm{pH}$ is high. Under such conditions most of the phosphorus content is converted to unavailable form, mainly as tricalcium phosphate. In such case, application of phosphate dissolving bacteria could increase the available phosphorus for plant and increased the efficiency of peanut plants in utilizing phosphorus fertilizer, which in turn had favourable effect on peanut productivity. Many investigators reported that the forementioned cultural practices i.e. high yielding varieties as well as phosphorus and bio fertilization increased peanut yield, yield attributes and yield quality (Madny, 1998; Migawer and Soliman, 2001; Abd-Allah, 2004; Ali et al., 2004; Attia, 2004; Maha, 2004; Yasien, 2005 and Mohamed, 2010 concerning peanut varieties, and Kabesh et al., 1987; Bahr, 1997; Detroja et al., 1997; Abdel- wahab et al., 1999; El- Dsouky and Attia , 1999; Borse et al., 2002; More et al., 2002; El- habbasha et al., 2005; Mirvat et al., 2006; Rahman, 2006; Gunri and Nath, 2012 and Rahman et al., 2012 concerning phosphorus and bio fertilization).

So, the aim of this work was to study the response of yield, yield attributes and yield quality of two peanut varieties to phosphorus and bio fertilization under new reclaimed sandy soil conditions. 
MATERIALS AND METHODS

Two field experiments were conducted during2012 and 2013 seasons in the Experimental farm of the Agricultural Research Station, Agric. Res. center at Ismailia, Egypt to study the effect of phosphorus and biofertilization on yield, yield components and yield quality of two peanut varieties, Giza 6 as erect $\mathrm{cv}$ and Gereogry as spread cv. to. Chemical analysis and physical properties of the experimental sites are stated in Table (1). These analysis were carried out using standard methods described by Piper (1950) and Jackson (1976).

Each experiment consisted of 24 treatments which were the combination of two peanut varieties (Giza 6 and Gereogry) and four levels of phosphatic fertilization $\left(0,100,150,200 \mathrm{~kg} /\right.$ fad (faddan $\left.=4200 \mathrm{~m}^{2}\right)$ in form of calcium superphosphate $\left(15.5 \% \mathrm{P}_{2} \mathrm{O}_{5}\right)$, i.e. $0,15.5$, 23.25 and $31 \mathrm{~kg} \mathrm{P}_{2} \mathrm{O}_{5} /$ fad, combined or not combined with applying biofertilizers phosphorine (contains Bacillus megatherium) or microbin (contains Azotobacter spp., Azospirillum spp., Pseudomonas spp., Bacillus megatherium and Rhizobium spp.). The factorial experiment in split plot design with three replications was made in use, where peanut cvs were allocated in the main plots and $\mathrm{P}_{2} \mathrm{O}_{5}$ levels with and without phosphorine or microbine in the sub plots. Each experimental sub plot consisted of 6 ridges $4 \mathrm{~m}$ in length and $60 \mathrm{~cm}$ in width $\left(4 * 3.6=14.4 \mathrm{~m}^{2}\right)$.

Phosphorus fertilizer at the mentioned rates as well as a basal dose of $15 \mathrm{~kg} \mathrm{~N} /$ fad and $24 \mathrm{~kg} \mathrm{~K} \mathrm{~K}_{2} \mathrm{O} /$ fad for all experiments were applied to the soil during preparing the land. All seeds of peanut cvs Giza- 6 and Gereogry were coated by arab gum and inoculated with the specific Rhizobium strain. Then the seeds were sown by hand on one side of the ridge in hills $10 \mathrm{~cm}$ apart for Giza- 6 and $20 \mathrm{~cm}$ apart for Gereogry on $20^{\text {th }}$ May in the first season 2012 and on $25^{\text {th }}$ May in the second season 2013 and the preceding crop was Egyptian clover in the two growing seasons. The biofertilizers (phosphorine or microbin) was mixed with moisten sand and drilled beside seedlings after 5 days from sowing. After 20 days from sowing peanut plants were thinned to one plant per hill, then the other cultural practices of growing peanut at Ismailia Governorate were followed as normal.

At harvest, (after 120 days from sowing for Giza 6 cv and after 140 days from sowing for Gereogry cv) five guarded plants were randomly taken from the inner ridges of each sub plot to determine yield components (plant height, number and dry weight of pods/plant, dry weight of seeds and straw/plant, 100-seed wt and shelling percentage. While, pod yield ( $\mathrm{ardab} / \mathrm{fad})$, seed yield ( $\mathrm{kg} / \mathrm{fad})$, fodder yield (ton/fad) and biological yield $(\mathrm{kg} / \mathrm{fad})$ were determined from the plants of the two middle rows (the $3^{\text {rd }}$ and $4^{\text {th }}$ ridges) in each sub plot and yields/fad were calculated.

Seed oil content \% was determined by using the modified soxhlet apparatus and petroleum ether as a solvent, according to A.O.A.C. (1980) then oil yield "kg/fad": was estimated by multiplying seed oil percentage by seed yield/fad. While seed protein content $\%$ was determined according to method Lowery et al. (1951) which mentioned by Sadasivan and Manickam
(1991). The concentration of protein in the sample could be estimated via reading the absorbance (at $750 \mathrm{~nm}$ ) using a spectrophotometer (Shimadzu, UV-2450, Tokyo, Japan). The concentration of protein in the sample compared against a standard curve of protein solution (in our case; Bovine Serum Albumin- BSAsolution) and protein yield ( $\mathrm{kg} / \mathrm{fad})$ was estimated by multiplying protein percentage by seed yield/fad.

Statistical analysis of the data obtained from each trail was subjected to the analysis of variance of split plot design as described by Snedecor and Cochran (1967). Combined analysis of variance for the two seasons was taken using the appropriate analysis of variance according to Leclery et al. (1966). Treatments means were compared using the least significant difference (LSD) test developed by Waller and Duncan (1969) at $0.5 \%$ level. Generally, the interactions between the two studied factors (cvs. and $\mathrm{P}$ with and without bio fertilizations) on peanut yield, yield components and yield quality did not reach the $0.5 \%$ level of significance, consequently the data for these interactions were excluded.

Table (1): Some physical and chemical properties of the experimental soil in the two seasons of investigation (2012 and 2013).

\begin{tabular}{|c|c|c|}
\hline Properties & $\begin{array}{c}\text { First season } \\
2012\end{array}$ & $\begin{array}{c}\text { Second } \\
\text { season } 2013\end{array}$ \\
\hline \multicolumn{3}{|l|}{ Physical analysis: } \\
\hline Coarse sand (\%) & 74.60 & 72.50 \\
\hline Fine sand $(\%)$ & 18.50 & 18.65 \\
\hline Silt (\%) & 2.45 & 3.50 \\
\hline Clay $(\%)$ & 4.45 & 5.35 \\
\hline Texture grade & Sandy & Sandy \\
\hline \multicolumn{3}{|l|}{ Chemical properties: } \\
\hline $\mathrm{pH}$ & 7.86 & 7.90 \\
\hline $\mathrm{EC} \mathrm{dsm}^{-1}$ & 0.125 & 0.13 \\
\hline OM \% & 0.42 & 0.53 \\
\hline $\mathrm{Ca} \mathrm{CO} \mathrm{CO}_{3}$ & 1.95 & 2.13 \\
\hline \multicolumn{3}{|l|}{$\begin{array}{l}\text { Soluble cations } \\
\text { meq/100 g soil }\end{array}$} \\
\hline $\mathrm{Ca}^{2+}$ & 0.20 & 0.40 \\
\hline $\mathrm{Mg}^{2+}$ & 0.10 & 0.30 \\
\hline $\mathrm{Na}^{+}$ & 0.22 & 0.58 \\
\hline $\mathrm{K}^{+}$ & 0.10 & 0.13 \\
\hline \multicolumn{3}{|l|}{$\begin{array}{l}\text { Soluble anions } \\
\text { meq/100 g soil }\end{array}$} \\
\hline $\mathrm{HCO}_{3}^{-}$ & 0.25 & 0.63 \\
\hline $\mathrm{Cl}-$ & 0.22 & 0.68 \\
\hline $\mathrm{SO}_{4}{ }^{2-}$ & 0.15 & 0.30 \\
\hline \multicolumn{3}{|l|}{$\begin{array}{l}\text { Available NPK } \\
\text { (ppm) }\end{array}$} \\
\hline $\mathrm{N}$ & 18.21 & 21.32 \\
\hline $\mathrm{P}$ & 4.85 & 5.78 \\
\hline $\mathrm{K}$ & 63.45 & 73.20 \\
\hline
\end{tabular}




\section{RESULTS AND DISCUSSION}

Table (2) shows the effect of phosphorus fertilization with and without biofertilizers phosphorine or microbein on yield, yield components and yield quality of two peanut varieties.

It is clearly evident from the data presented in Table (2) that over phosphorus and bio fertilizers. The spread variety Gereogry surpassed significantly the erect variety Giza 6 in yield (pods, seeds, fodder and biological yield/fad), yield components (plant height, number and dry weight of pods/plant, dry weight of seeds /plant, 100-seed weight and shelling percentage) and yield quality (seed oil content $\%$ and oil and protein yield/fad). While, the two studied varieties did not differ significantly from each other in dry weight of straw /plant, straw yield /fad and seed protein content \%). Some investigators found varietal differences between the two studied cvs., Gereogry and Giza 6 in peanut yield, yield components and yield quality (Yasein, 2005 and Mohamed, 2010).

Also, over varieties, the data illustrated in Table (2) show that increasing phosphorus levels from 0 to 31 $\mathrm{kg} \mathrm{P}_{2} \mathrm{O}_{5} / \mathrm{fad}$ increased significantly the forementioned yield, yield components and yield quality, except the non significant effect of $\mathrm{P}$ levels on seed protein content $\%$. It is worthy to note that bio fertilizers phosphoriene or microbein increased the efficiency of peanut plants in utilizing phosphorus fertilizer, which in turn had favourable effect on peanut productivity. The increment of yield, yield component and yield quality of peanut was more pronounced and its values were higher when peanut plants fertilized with phosphorus fertilizer combined with phosphorine or microbein than fertilized with $\mathrm{P}$ only and the two biofertilizers did not differ significantly in this respect. This might be attributed to that fertilization with any of the two bio fertilizers converted the unavailable phosphorus as tricalcium phosphate to the available phosphorus. That led to enhance the efficiency of peanut plants in utilizing phosphorus fertilizer which in turn had favourable effects on peanut productivity. $\mathrm{P}$ levels up to the highest level (31 kg $\mathrm{P}_{2} \mathrm{O}_{5} /$ fad with or without biofertilizers) increased significantly peanut yield, yield components and yield quality, except that there was no significant difference between tow higher levels of $\mathrm{P}$ (23.25 and $31.0 \mathrm{kgP}_{2} \mathrm{O}_{5} /$ fad) in plant height, 100 -seed weight, pod yield/fad, seed oil content $\%$ and protein yield/fad). Many investigators reported that forementioned cultural practices i.e. high yielding varieties as well as phosphorus and bio fertilization increased peanut yield, yield attributes and yield quality (Madny, 1998; Migawer and Soliman, 2001; Abd-Alla, 2004; Ali et al., 2004; Attia, 2004; Maha, 2004; Yasein, 2005 and Mohamed, 2010, concerning peanut varieties and kabesh et al., 1987; Bahr, 1997; Detroja et al.,1997; Abdel -Wahab et al., 1999; El-Dsouky and Attia, 1999; Borse et al., 2002; More et al., 2002; El- Haabbasha et al., 2005; Mirvat et al., 2006; Rahman, 2006; Gunri and Nath, 2012 and Rahman et al., 2012, concerning phosphorus and bio fertilization). The higher productivity of the spread variety Gereogry (pods, seeds, fodder and biological yield/fad) which fertilized with $\mathrm{P}$ levels up to the highest level $\left(31 \mathrm{~kg} \mathrm{P}_{2} \mathrm{O}_{5} / \mathrm{fad}\right)$ with and without biofertilizers phosphorine or microbein, compared to the erect variety Giza 6, attributed to the superiority of Gereogry in the forementioned yield components. Also, as mentioned in the first paper on peanut growth ( Abdel-Haliem, S. Manal et al., 2015), the studied factors resulted in vigorous vegetative growth and growth characters in their good performance, which controlled peanut yield and reflected directly on high yielding ability. Vegetative organ is the source of photosynthesizes formation, which translocation to the sink (seeds). Moreover, Hanway (1962) found a positive correlation between dry matter accumulation in the leaves and yield of maize.

The interaction between peanut varieties and phosphorus fertilizers with or without any of the two studied bio fertilizers phosphorine and microbin did not exert significant effect on peanut yield, yield components and yield quality, which means that each factor act independently. Therefore the data of the interaction were excluded.

\section{REFERENCES}

A. O. A. C. (1980). Association of official analytical chemists, official methods of analysis. $13^{\text {th }} \mathrm{Ed}$, Washington, D. C.

Abd-Alla, M. M (2004). Effect of certain agricultural practices on productivity of peanut. 1 . Influence of sowing dates and potassium application on yield and yield attributes of some peanut cultivars. Zagazig J. Agric. Res., 31(3):843-866.

Abdel-Haleim, S. Manal, M.H. Abdel-Mottaleb, G.M. Yakout, A.M. Abdel-Wahab and A.A. Nasef (2015). Effect of bio fertilization in increasing the efficiency of two peanut varieties in utilizing of phosphorus fertilization: 1- Effect on growth. J. Plant Production Sci., Suez Canal Univ. (Accepted).

Abdel- Wahab, A. M., G. M. Yakout, E. A. Ali and M. H. Greish (1999). Response of soybean crop to phosphatic fertilization, organic manuring and biofertilization under new reclaimed sandy soil conditions. Egypt. J. Appl. Sci., 14(8):125-138.

Albert, E. (1978). Pot experiments for determining favourable NPK and PK ratio to be applied to spring wheat and red clover. Acker und Pflanzenbau, 22(4): 241- 251.

Ali, A. A. G, O. A. Zeiton, H. G. M. Geweifel and M. A. Taha (2004). Some factors affecting productivity of peanut (Arachis hypogaea L.) in newly cultivated sandy soil. Zagazig J. Agric. Res., 31(6): 2565- 2595.

Attia, K. K. (2004). Response of two peanut varieties to phosphorus fertilization and foliar application of certain micronutrients under sandy calcareous soil conditions. Assiut J. Agric. Sci., 35(4): 253-267.

Bahr, A. B. (1997). Response of chickpea crop to some fertilization treatments. Ph. D. Fac. Agric., Suez Canal Univ, Egypt, pp 173.

Borse, N. S., L. K. Patel, Y. G. Patil, P. K. Rathod and B. M. Kamble (2002). Integrated nutrient 
management in summer groundnut. Advances in Plant Sci., 21(1): 329-331.

Detroja, K. S., D. D. Malavia, B. B. Kaneria, V. D. Khanapra and R. K. Patel (1997). Effect of phosphatic fertilizer, phosphobacteria and seed size on plant stand, growth and yield of summer groundnut (Arachis hypogaea). Indian J. Agron., 42(3): 495-497.

El-Dsouky, M. M. and K. K. Attia (1999). Effect of inoculation with phosphate solubilizing bacteria, Organic manuring and phosphate fertilization on peanuts grown on sandy calcareous soil. Assiut J. of Agric. Sci., 30(5): 1999.

El-Habbasha, S. F., A. A. Kandil, N. S. Abu-Hagaza, A. K. A. El-Haleem, M. A. Khalafallah and T. G. Behairy (2005). Effect of phosphorus levels and some bio-fertilizers on dry matter, yield and yield attributes of groundnut. Bull. Fac. Agric., Cairo Univ., 56(2): 237-252.

Gunri, S. K. and R. Nath (2012). Effect of organic manures, biofertilizers and biopesticides on productivity of summer groundnut (Arachis hypogeae L.) in red and laterite zone of West Bengal. Legume Res., 35(2): 144-148.

Hafiz, S. I. (2007). Influence of bio and mineral phosphatic fertilization and spraying with micronutrients on peanut crop in newly reclaimed sandy soils. Egypt. J. Appl. Sci., 22: 169-187.

Hanway, J.J. (1962). Corn and composition in relation to soil fertility. 1. Growth of different plant parts and relation between leaf weight and grain yield. Agron. J., 54: 145-148.

Jackson, M.L. (1967). Soil Chemical Analysis. Prentic Hall Private Itd., New York,USA.

Kabesh, M.O., M. S. M, Saber and T. G. Behairy(1987). Utilization of biofertilizers in field crop production. 1- Effect of the increasing rates of phosphatic fertilizer with and without biofertilization on growth and yield of soybean plants in pot experiments. Egypt. J. Agron., 12(12): $123-130$.

Leclery, E. L., W. H. Leonard and A. G. Clark (1966). Field plot technique. Brugross Publishing CoMinneopolis, Minnesota, USA.

Lowery, O. H., N. J. Rosebrough, A. L. Farr and R. J. Randall (1951). Protein measurement with the folinphenol reagent. j. Biol. Chem., 193: 265-275.

Madny, A. M. (1998). Growth analysis and yield response of certain peanut cultivars to phosphorus fertilization and micronutrients. M. Sc. Thesis, Fac. Agric., Ain Shams Univ. pp 129.
Maha, M. Abd-Alla (2004). Effect of certain agricultural practices on productivity of peanut. 1. Influence of sowing dates and potassium application on yield and yield attributes of some peanut cultivars. Zagazig J. Agric. Res., 31(3): 843-866.

Marschner, H. (1986). Mineral nutrition of higher plants. Academic Press INC, USA, pp 674.

Migawer Ekram A. and Mona A.M. Soliman (2001). Performance of two peanut cultivars and their response to NPK fertilization in newly reclaimed loamy sand soil. J. Agric Sci. Mansoura Univ., 26(11): 6653-6667.

Mirvat E. Gobarah, Magda H. Mohamed and M. M. Tawfik (2006). Effect of phosphorus fertilizer and foliar spraying with zinc on growth, yield and quality of groundnut under reclaimed sandy soils. J. Appl. Sci. Res., 2(8): 491-496.

Mohamed, M. A. H. (2010). Response of some peanut varieties to potassium and foliar application with boron at the New Valley. Ph. D. Thesis, Fac. Agric., Assiut Univ., Egypt, pp 674.

More, K. A., C. B. Gaikwad and D. V. Dahat (2002). Effect of N, P, Rhizobium and phosphate solubilizing bacteria on groundnut. J. Maharashtra Agric. Univ., 27(2): 202-204.

Piper, C. S.(1950). Soil and Plant Analysis. Inter. Science Publishers Inc., New York, USA. pp 368.

Rahman, M. A. (2006). Effect of calcium and Bradyrhizobium inoculation of the growth, yield and quality of groundnut (Arachis hypogaea L.). Bangladesh J. Sci. and Indust. Res., 41(3/4): 181188.

Rahman, M. A., M. A. R. Sarkar, A. M. Islam, M. M. Rahman and M. Ahmed (2012). Effect of phosphorus and bradyrhizobium inoculation on yield and seed quality of groundnut under shallow red brown terrace soil. Int. J. Sustainable Agric. Tech., 8(1): 7-14.

Russel, E. W. (1973). Soil conditions and plant growth. Language Book Society and Longman, London, pp 30-37.

Sadasivan and Manickam (1991). Biochemical Methods for Agricultural Sciences, pp 921- 957.

Snedecor, G.W. and W.G. Cochran (1967). Statistical methods. $8^{\text {th }}$ ED., Iowa State Univ., Press, Ames, Iowa, U. S. A.

Waller, R. A. and D. B. Duncan (1969). Abays rule for the symmetric multiple comparisons problem. Am. Stat. Assoc. J. Dec., 1485 p.

Yasein, M. A. T. (2005). Some factors affecting yield and seed quality of peanut (Arachis hypogaea L.). M. Sc. Thesis, Fac. Agric. Zagazig Univ., 167 p. 


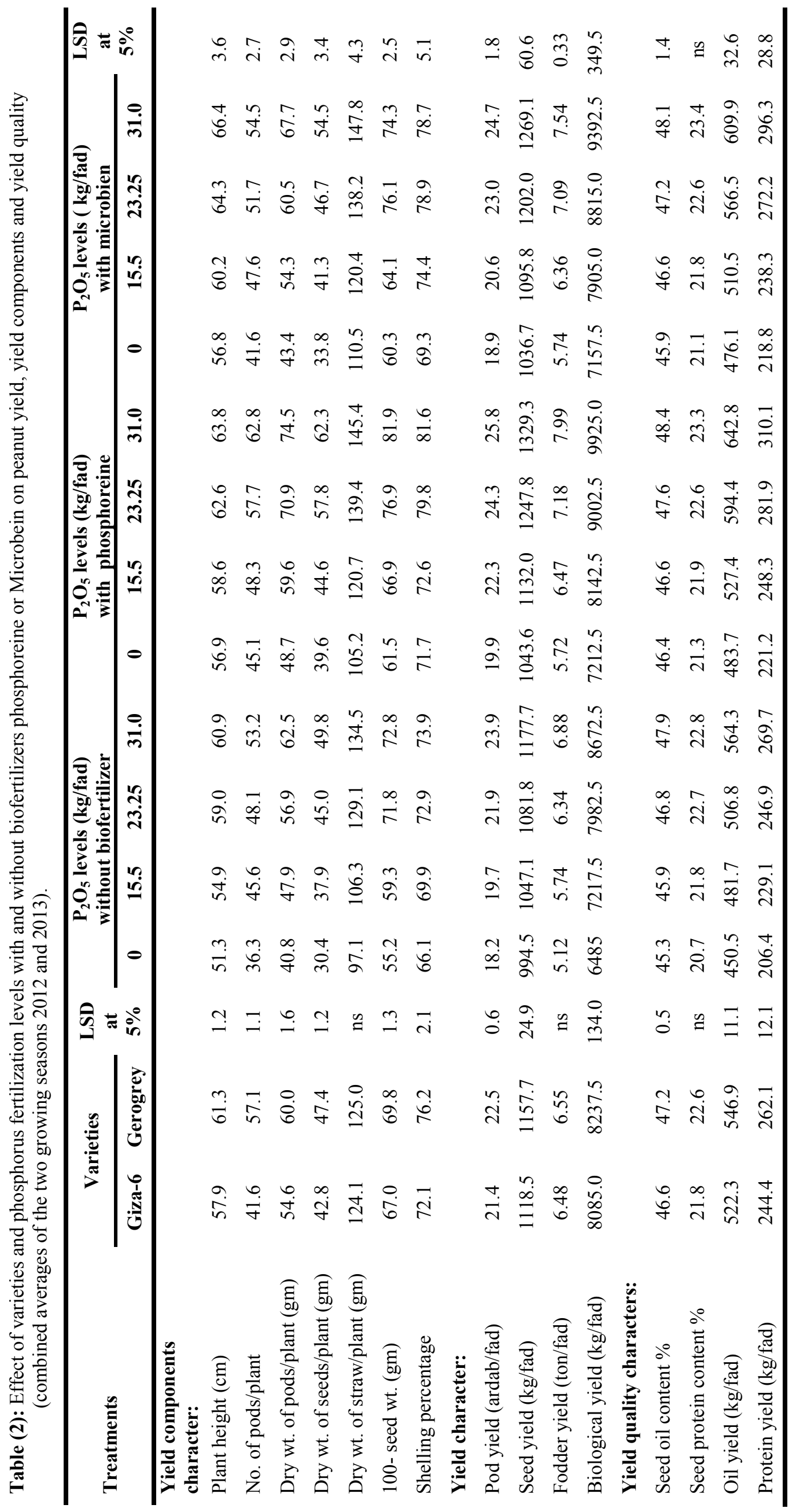




\section{تأثثر التسميد الحيوي في زيادة كفاءة صنفين من الفول السوداني في الاستفادة من التسميد الفوسفاتي:

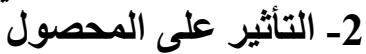

منال شكرى عبد الحليم"، جمال محمد ياقوت"، حسن محمد عبد المطلب"، عبد القتاح محمد عبد الوهاب"، على ناصف على عبد العال**

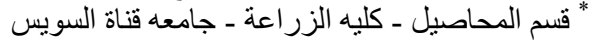

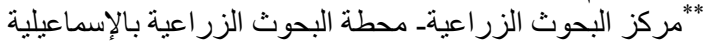

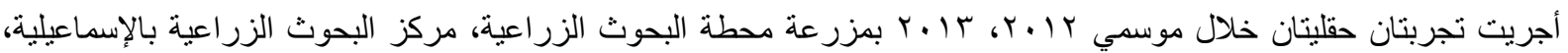

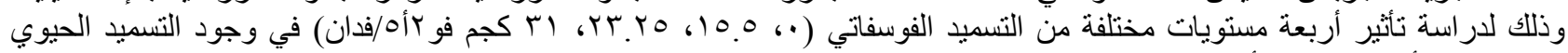

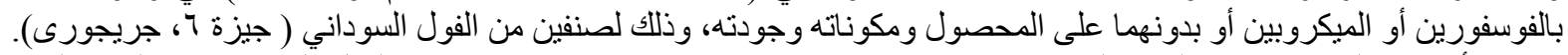

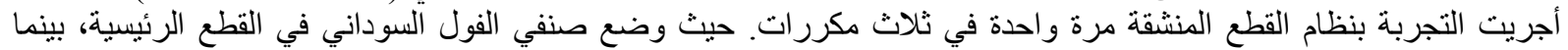

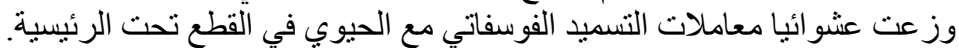

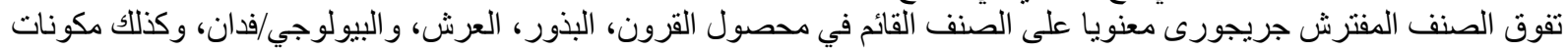

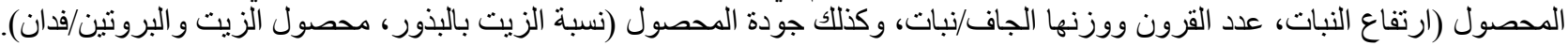

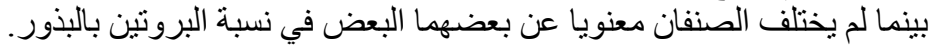

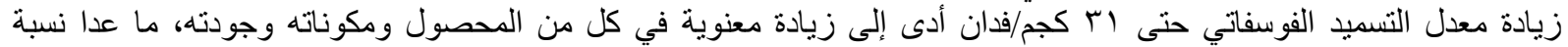

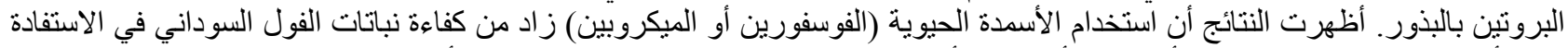

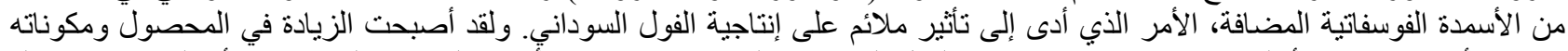

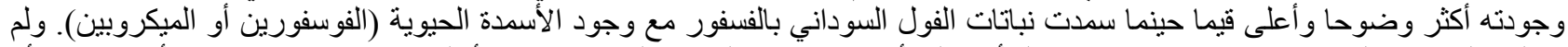

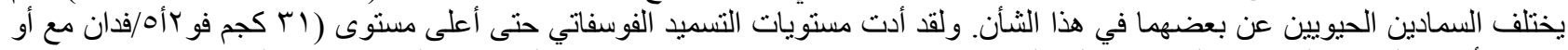

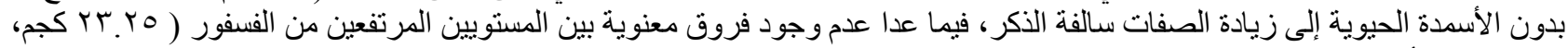

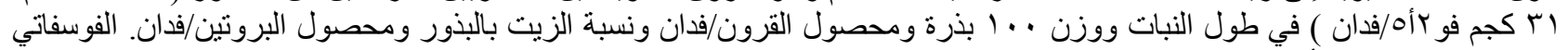

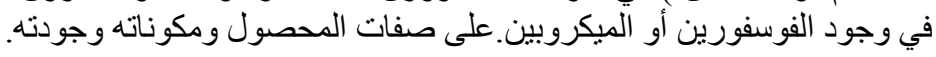

